
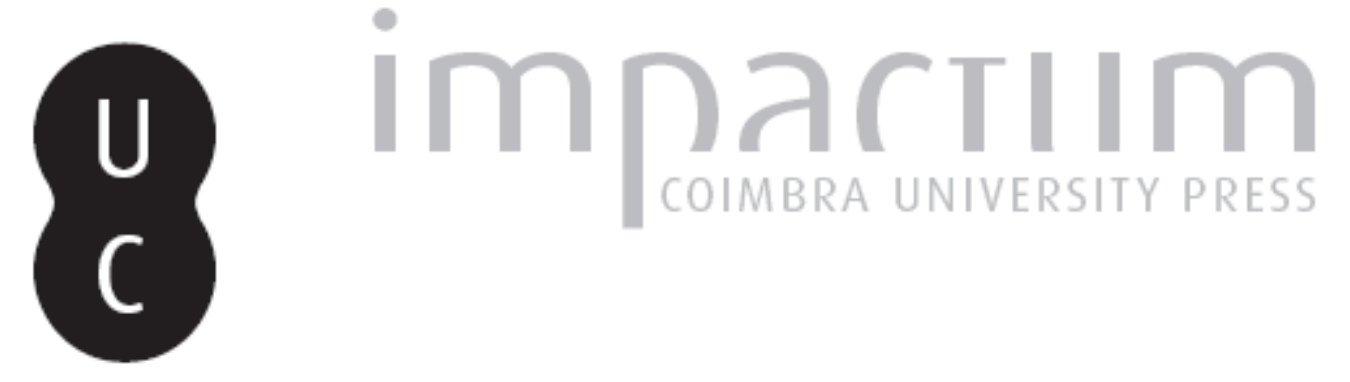

Virtue, practice, and perplexity in Plato's Meno

Autor(es): Wians, William

Publicado por: Imprensa da Universidade de Coimbra

URL persistente: URI:http://hdl.handle.net/10316.2/42172

DOI: $\quad$ DOI:https://doi.org/10.14195/2183-4105_12_6

Accessed : $\quad$ 26-Apr-2023 03:48:29

A navegação consulta e descarregamento dos títulos inseridos nas Bibliotecas Digitais UC Digitalis, UC Pombalina e UC Impactum, pressupõem a aceitação plena e sem reservas dos Termos e Condições de Uso destas Bibliotecas Digitais, disponíveis em https://digitalis.uc.pt/pt-pt/termos.

Conforme exposto nos referidos Termos e Condições de Uso, o descarregamento de títulos de acesso restrito requer uma licença válida de autorização devendo o utilizador aceder ao(s) documento(s) a partir de um endereço de IP da instituição detentora da supramencionada licença.

Ao utilizador é apenas permitido o descarregamento para uso pessoal, pelo que o emprego do(s) título(s) descarregado(s) para outro fim, designadamente comercial, carece de autorização do respetivo autor ou editor da obra.

Na medida em que todas as obras da UC Digitalis se encontram protegidas pelo Código do Direito de Autor e Direitos Conexos e demais legislação aplicável, toda a cópia, parcial ou total, deste documento, nos casos em que é legalmente admitida, deverá conter ou fazer-se acompanhar por este aviso. 
O

Established 1989

$\bigcirc$

$\vdash$

$<$

$\dashv$

ㅇ

-
$Z$
0
-
1
$Z$
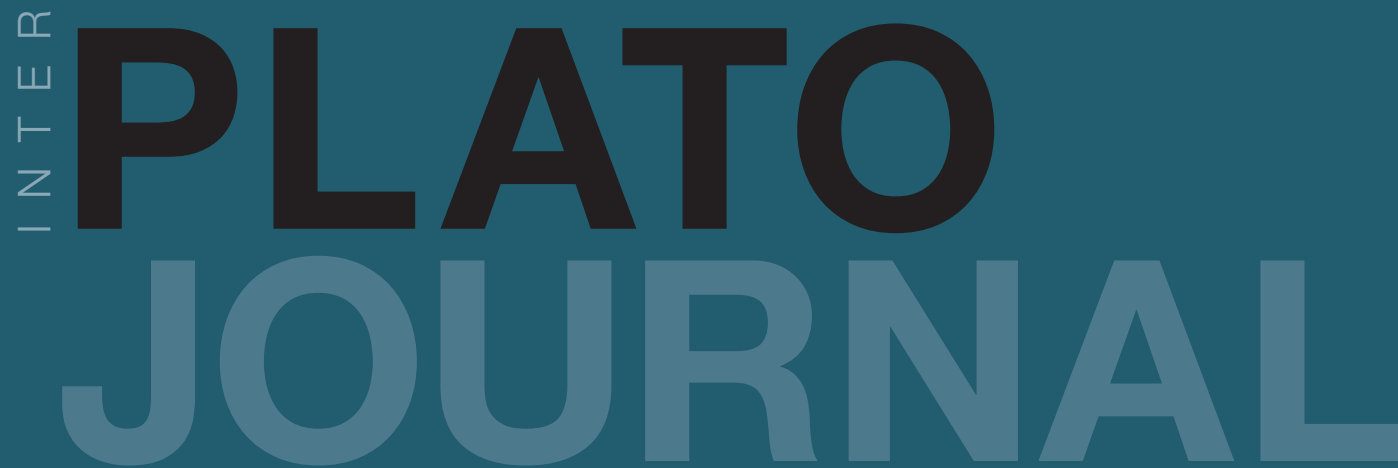

Société Platonicienne Internationale

Associazione Internazionale dei Platonisti

Sociedad Internacional de Platonistas

Internationale

Platon-Gesellschaft 


\title{
VirTUe, PRACTICE, AND PERPLEXITY IN PLATO'S MENO
}

\author{
William WIANS
}

Plato's Meno presents a deceptively simple surface. Plato begins by having his character Meno ask Socrates how virtue is acquired. Instead of having Socrates respond directly, Plato has him divert the conversation to the question of what virtue is. But Plato's Meno isn't accustomed to the rigors of Socratic inquiry, and so Plato allows him to force the discussion back toward a version of his original question. After a series of false starts and frustrations, Plato ends his dialogue with his characters unable to define virtue or to supply a persuasive answer as to how it is acquired.

The Meno has been called a perfect example of the essential points of Platonism. ${ }^{1}$ If the dialogue is characteristic of Plato, however, it has as much to do with what it shows the reader about virtue as with what it tells. ${ }^{2}$ Though the aggressively confident Meno certainly ends unable to define virtue, and Plato's Socrates is often said to do so, I shall argue that Plato is in no doubt as to what virtue is or the means by which virtue is acquired. I shall organize my argument around what we find in two key passages - and crucially, what we find missing. In them, Plato provides clues to the meaning of the whole, connecting the perplexity of the dialogue's two main characters with the most promising route toward the acquisition of virtue, a route that is surprisingly neglected over the course of the dialogue.

I shall also work to keep the authorial dimension in view. That is, rather than saying simply that Socrates says this or Meno says that, I shall emphasize that it is Plato who makes Socrates and Meno say what he, the author, wants to

\footnotetext{
1 "In the Meno ... more that is characteristic of Plato is brought together in a smaller space than in any other dialogue." J. S. Mill, Dissertations, 3.350; W. Pater, Plato and Platonism, 52s: "that most characteristic dialogue." Both are quoted by E. S. Thompson, The Meno of Plato [Meno] (London: Macmillan, 1901; rpt. Garland Publishing, 1980), xxv.

${ }^{2}$ As Klein puts it "answers can be given in a written text by the very action it presents.... This also confers on the dialogues the quality of completeness as against their unfinished (aporetic) character in terms of the verbal argument." Jacob Klein, A Commentary on Plato's Meno 2 As Klein puts it "answers can be given in a written text by the very action it presents. . . This also confers on the dialogues the quality of completeness as against their unfinished (aporetic) character in terms of the verbal argument." Jacob Klein, A Commentary on Plato's Meno [Commentary] (University of North Carolina Press, 1965), 17.
}

PLATO, The electronic Journal of the International Plato Society, 12, 2012.

http://gramata.univ-paris1.fr/Plato/article117.html,

(c) All rights of reproduction of any form reserved. 
have said and be left unsaid at each point. ${ }^{3}$ While the importance of the literary and dramatic aspects of Plato's philosophical dramas is now often noted, too many commentators persist in speaking of what Socrates and his interlocutors want, intend, or are feeling, rather than confining themselves to what Plato has them say. In doing so, they obscure the critical distance between an author and his creation and risk turning a carefully plotted philosophical dialogue into a psychological study of its characters. ${ }^{4}$ Plato uses the dramatic structure of the Meno ultimately not to support but actually to counter the apparent failure of his characters, pointing the reader in the right direction even as he has Socrates' headstrong companion insist on pursuing the wrong way.

\section{1.}

Plato begins the dialogue abruptly:

MENO: Can you tell me, Socrates, whether virtue (aretê) is something teachable (didakton)? Or is it not teachable, but something acquired through practice (askêton)? Or is it neither acquired through practice nor something learned (mathêton), but comes to be present (paragignetai) in human beings by nature (phusei), or in some other way? (70a 1-4)

The Meno begins without the brilliant scene setting of the Protagoras and Gorgias or even the more prosaic prelude of the Euthydemus, dialogues typically dated

\footnotetext{
${ }^{3}$ A point put bluntly by Kahn: Socrates is both "Plato's historical master and his literary puppet" (p. 35); Charles Kahn, "Did Plato Write Socratic Dialogues?” in H. Benson (ed.), Essays on the Philosophy of Socrates (Oxford: Oxford University Press, 1992), 35-52; originally in Classical Quarterly 31, 305-20. Sallis invokes an earlier series of commentators by saying "nothing is accidental in a Platonic dialogue"; John Sallis, Being and Logos (Atlantic Highlands, NJ: Humanities Press International), 17 and note 7.

${ }^{4}$ Penner expresses precisely the essential literary quality of the dialogues I wish to emphasize: "Plato's dialogues are most extraordinarily finely crafted and plotted pieces of work" (my emphasis), in Terrence Penner, "The Death of the so-called 'Socratic Elenchus'," in M. Erler and L. Brisson (eds.), Gorgias-Menon: Selected Papers from the Seventh Symposium Platonicum [Erler and Brisson (eds.), Gorgias-Menon] (Stuttgart: Academia Verlag, 2007), 3-19. The quotation is on p. 4. I would say that Plato makes the same point using an organic metaphor at Phdr. 264c2-5. The possibility that Plato could have been present for an actual conversation between the historical Meno and Socrates (see A. E. Taylor, Plato: The Man and his Works [Plato] [London: The Dial Press, 1936], 130) should not distract the reader from the literary character and especially the careful plotting of the dialogue as we have it.

${ }^{5}$ Translations are my own, made with an eye on those of Robert Sharples, Plato: Meno [Meno], (Oxford: Aris and Phillips, 2004; revised and updated edition of 1985), and George Anastaplo and Lawrence Berns, Plato's Meno (Newburyport: Focus Publishing, 2004). I have followed the text and line numbering in Sharples.
}

PLATO, The electronic Journal of the International Plato Society, 12, 2012.

http://gramata.univ-paris1.fr/Plato/article117.html,

(C) All rights of reproduction of any form reserved. 
close to the Meno. ${ }^{6}$ Plato has Meno ask how a person acquires or comes to possess aretê, virtue or excellence. ${ }^{7} \mathrm{He}$ is made to name three possibilities, with a fourth alternative amounting to "none of the above" leaving room for the suggestion at the end of the dialogue that virtue is a theia moira, a divine allotment or "gift of the gods."

The options would be familiar to Plato's audience. From the arrival of the Sophists in the mid-fifth century, the question of how aretê could be acquired was part of the current debate, as was the question of what aretê itself was. Sophists often claimed to be able to teach the virtue or excellence necessary to succeed in the public or political sphere and so made its acquisition an urgent need for ambitious young men. ${ }^{8}$ The question was equally urgent for the founder of the Academy, as its prominence not just in the Meno but in the Protagoras, Laches, Euthydemus, Gorgias, and Republic indicates.'

\footnotetext{
${ }^{6}$ Explanations for the Meno's abrupt opening are offered by Dominic Scott, Plato's Meno [Plato's Meno] (Cambridge: Cambridge University Press, 2006), 11-13; H. Tarrant, Recollecting Plato's Meno [Recollecting] (London: Duckworth, 2005), 17-20; Roslyn Weiss, Virtue in the Cave: Moral Inquiry in Plato's Meno [Cave] (Oxford: Oxford University Press, 2001), 18-19; Jill Gordon, Turning Toward Philosophy [Turning] (University Park: The Pennsylvania State University Press, 1999), 101; Francisco Gonzalez, Dialectic and Dialogue: Plato's Practice of Philosophical Inquiry [Dialectic] (Evanston: Northwestern University Press, 1998), 154; Alexander Nehamas, "Meno's Paradox and Socrates as Teacher" ["Socrates as Teacher"], Oxford Studies in Ancient Philosophy 3 (1985): 1-30; Robert Sternfeld and Harold Zyskind, Plato's Meno: A Philosophy of Man as Acquisitive [Acquisitive] (Carbondale: Southern Illinois University Press, 1978), 20-22; Klein, Commentary, 38; R. S. Bluck, Plato's Meno (Cambridge: Cambridge University Press, 1961), 199; R. G. Hoerber, "Plato's Meno", Phronesis 5 (1960): 78-102; and Taylor, Plato, 130 and 131-2, among others.
}

7 Translating aretê into English is a standing problem. The two most common alternatives are virtue and excellence. W. K. C. Guthrie, The Sophists [Sophists] (Cambridge: Cambridge University Press 1971), 253, credits Socrates with giving the word its strong moral emphasis; see also Gregory Vlastos, Socrates: Ironist and Moral Philosopher (Ithaca: Cornell University Press, 1991), 200. Indeed, one can see this in Plato's inductive move from the excellence of a well functioning body part to the (morally) excellent functioning of the soul at Rep. I, 353b2-e11. Because Plato in the Meno is most interested in aretê in the sense of moral virtue, virtue is the translation I prefer-though the character Meno is allowed to operate with the older sense of excellence in civic affairs; see further Bluck, Plato's Meno, 201-02.

${ }^{8}$ Plato's Protagoras promises to do precisely that at Protagoras 318e5-319a2, as does Plato's Hippias at Hippias Major 283c3-284a4. At 95c1-4, Meno denies that his teacher Gorgias claimed to teach aretê, a passage Dodds cites in arguing that Gorgias wasn't a Sophist: E. R. Dodds, Plato: Gorgias [Gorgias] (Oxford: Oxford University Press, 1959), 6-7. But Meno does not contrast Gorgias with the Sophists so much as he contrasts his teacher with other Sophists (tôn allôn; 95c3). Otherwise, his reply to Socrates' question at 95b9-10 about Sophists as teachers of aretê would be a non sequitur. Note also that Plato's Gorgias promoted his instruction with a promise of public success (Gorgias 452d5-e4; see also Hippias Major 282b4-c5), and says that a student who comes to him not knowing what is just, noble, or good will learn these things from him (460a3-4; but see Dodds' further remarks on 216-17, and Bluck, Plato's Meno, 205-206).

${ }^{9}$ For surveys of the historical situation, see Tarrant, Recollecting, 11-17 and 20-23 (with special emphasis on Plato's sharing in the general Greek spirit of competitiveness); R. S. Slings, Plato's

PLATO, The electronic Journal of the International Plato Society, 12, 2012.

http://gramata.univ-paris1.fr/Plato/article117.html,

(C) All rights of reproduction of any form reserved. 
Despite the intense interest surrounding the question of how virtue could be acquired, Plato's attention to the four options over the course of the dialogue is decidedly uneven. The dialogue concentrates on the first possibility, that virtue is teachable, almost to the exclusion of the others-so much so that many commentators speak as if "Is virtue teachable?" is the only question Meno asks. ${ }^{10}$ The third option, that virtue is a natural endowment, surfaces briefly in the second half of the dialogue but is quickly dismissed (89a6-b7). The possibility that virtue is a gift of the gods is raised only at the dialogue's end. The second option, that virtue is acquired through practice (askêsis), is simply not considered. It is raised in the opening lines, never to be mentioned again.

The neglect of practice by so careful a writer is surprising. When Aristotle opens the second book of the Nicomachean Ethics with essentially the same list of possibilities (1103a14-26), he says that moral virtue is acquired (periginetai) through the formation of proper habits. Aristotle uses the term ethos and not askêsis in this passage; however, he uses askêsis in the Meno-like list of options by which one might attain happiness at NE I 9, 1099b9-11, and identifies askêsis with habituation at $E E \mathrm{I} 1,1214 \mathrm{a} 15-22 .{ }^{11}$

At least twice in the Meno, Plato passes over opportunities to raise the option of acquiring virtue by practice. Following the conclusion of the geometry lesson, Plato has Meno ask Socrates to return to his original question of how virtue is acquired. But the only possibilities Plato has Meno name are those of teaching and by nature $(86 \mathrm{c} 7-\mathrm{d} 2)$. Then at the dialogue's end, Plato has Socrates suggest and the by now compliant Meno agree that virtue is a gift of the gods. But again, teaching and by nature are the only other options named by Plato's characters. The possibility of acquiring virtue through practice seems entirely

Clitophon [Clitophon] (Cambridge: Cambridge University Press, 1999), 106-108; Nehamas, "Socrates as Teacher," 2-4; G. B. Kerferd, The Sophistic Movement (Cambridge: Cambridge University Press, 1981), 131-138; Kenneth Dover, Greek Popular Morality (Berkeley and Los Angeles: University of California Press, 1974), 88-95; Guthrie, Sophists, 250-260; M. J. O’Brien, The Socratic Paradoxes and the Greek Mind [Paradoxes] (Chapel Hill: University of North Carolina Press, 1967), 144n27; Paul Shorey, "Phusis, Meletê, Epistêmê," Transactions of the American Philological Association 40 (1909): 185-201; Thompson, Meno, 57-58.

${ }^{10}$ This tendency is very widespread. Among those cited elsewhere in this paper, those who speak this way include Edward Halper, "A Lesson from the Meno" ["Lesson"], in Erler and Brisson (eds.), Gorgias-Menon, 234-242; Sharples, Meno, 4; Gordon, Turning, 93-94; Garreth Matthews, Socratic Perplexity and the Nature of Philosophy [Perplexity] (Oxford: Oxford University Press, 1999), 43; J. M. Day (ed.), Plato's Meno in Focus [Meno in Focus] (London: Routledge, 1994), 1, 3, 19; K. V. Wilkes, "Conclusions in the Meno" ["Conclusions"], Archiv für Geschichte der Philosophie 61: 143-153 (page numbers cited as reprinted in Day); Thompson, Meno, xxvi and 57; Bluck, Plato's Meno, 4. Initially Nehamas, "Socrates as Teacher," 2, represents Meno as asking whether aretê is "teachable, inborn, or acquired in some other way" (omitting practice). But by p. 4, this is reduced solely to the question of virtue's teachability. Both Sallis, Being and Logos, 94, and Sternfeld and Zyskind, Acquisitive, 20 and 51, are more careful, speaking of how virtue is acquired, though neither directly considers the option of practice.

${ }^{11}$ See also NE X 9, 1179b20-23.

PLATO, The electronic Journal of the International Plato Society, 12, 2012.

http://gramata.univ-paris1.fr/Plato/article117.html,

(C) All rights of reproduction of any form reserved. 
forgotten. ${ }^{12}$

Scholars have sought to account for the absence of an explicit discussion of practice in a variety of ways. Bluck and Sharples, less and more tentatively respectively, find an implicit rejection of practice in the criticisms of virtue as teachable in the second half of the dialogue. Castelnérac finds askêsis implicit in Socratic practices in the geometry lesson. Gonzalez and Hoerber (the latter using elaborate and sometimes obscure parallels between the three options and the structure of the dialogue as a whole) argue that Plato embraces all three. DesJardins finds senses in which all four options, including the theia moira, are implicitly endorsed as necessary for virtue's acquisition. Klein connects the omission of practice to flaws in Meno's character, but does not develop the connection systematically over the whole dialogue. ${ }^{13}$

Some scholars point to passages in other dialogues where Plato links practice or habit with an inferior kind of virtue. This is a demotic virtue practiced "without philosophy" (ethei aneu philosophias aretês; Rep. 619c7-d1), or "without philosophy or understanding" (aneu philosophias te kai nou; Phd. 82a11-b3; see also 68d2-69d3; 82b10-c8). Perhaps, it has been suggested, it was this sham virtue that Plato had in mind when he quietly dropped askêsis from consideration in the Meno. ${ }^{14}$ Indeed, we shall discover that a similar deficiency of acting aneu nou figures in the Meno.

The most recent and also the most radical solution is Dominic Scott's. Calling it a mystery that after the opening lines practice "is never mentioned again in the dialogue either to be developed or dismissed," Scott points to a manuscript (known as 'F') in which only the first and third options (plus "none of the above") are included to argue that acquiring virtue through practice may never have been part of Plato's Meno as originally written. ${ }^{15}$

\footnotetext{
${ }^{12}$ In at least one other passage practice could easily have been reintroduced. At 89a5-c7, Plato has Meno conclude that because a person is not made virtuous by nature, virtue must therefore be teachable, as if there is no third option. The omission of practice in this passage is noted by Scott, Plato's Meno, 18, and Thompson, Meno, 161. A further passage is noted by Bluck, Plato's Meno, 202, who thinks the quotation from Theognis at 95 d "would certainly have brought the idea of askêsis to mind" (see also p. 396); I will eventually return to this passage.

${ }^{13}$ Bluck, Plato's Meno, 202-03 ("an explicit rejection of [practice] might have been a tedious and unnecessary encumbrance"); Sharples, Meno, 123; B. Castelnérac, "Comment aqcuérir la vertu? La tripartition phúsus, áskesis, máthêsis dans le Ménon," in Erler and Brisson (eds.), GorgiasMenon, 223-227; Gonzalez, Dialectic; 173; Hoerber, "Plato's Meno" (Hoerber's approach is criticized in R. S. Bluck, "Plato's Meno," Phronesis 6: 94-101); Rosemary DesJardins, "Knowledge and Virtue: Paradox in Plato's Meno" ["Virtue"], Review of Metaphysics 39 (December 1985): 261-281; Klein, Commentary, 1965. For a cogent argument against finding an implicit rejection of practice in the explicit rejection of teaching, see Scott, Plato's Meno, 17n22.

${ }^{14}$ This is essentially the position of Taylor, Plato, 131 and 144-145. See also Bluck, Plato's Meno, 40-41; Thompson, Meno, 59 and 228-229.

${ }^{15}$ Scott, Plato's Meno, 16-18. Scott finds some additional support for his position in the spurious Platonic dialogue On Virtue (18n24), which resembles the Meno in some respects, but like F omits
}

PLATO, The electronic Journal of the International Plato Society, 12, 2012.

http://gramata.univ-paris1.fr/Plato/article117.html,

(C) All rights of reproduction of any form reserved. 
The absence of practice in the Meno is indeed a puzzle. I shall argue that for reasons having everything to do with the point of the dialogue Plato allows his interlocutors to pass over the second option even at the cost of having his characters' inquiry fail. I shall proceed as follows. I will begin by working to clarify the differences between the four alternatives for acquiring virtue. I'll then turn to the dialogue's concluding speeches and the second of the two passages where the omission of practice is most conspicuous. Finally, I'll return to earlier parts of the dialogue in which Plato prepares for the failure of his characters. Making a case for an option that seems to have been forgotten will require a good deal of attention to several extended passages from the dialogue. But doing so will reveal a carefully plotted presentation that points the reader toward a true understanding of virtue and the sort of practice needed to acquire it.

Meno has been criticized for presenting his opening options as if they were mutually exclusive. ${ }^{16}$ Why Plato may have made him do so requires a closer look at the four alternatives eventually canvassed in the dialogue-Meno's original triad plus Socrates' concluding suggestion that virtue is a gift of the gods.

We may begin by observing that the four possible ways of acquiring virtue form a mutually exhaustive set of possibilities. At the broadest level, either one must work to acquire virtue, or no work is required. If no work is needed, then virtue is present in those who possess it either naturally (as Pindar might say, pointing to a patron's aristocratic origins), or supernaturally, as a gift from the

practice in its opening lines. But this pale Academic cribsheet, just four Stephanus pages long as compared to the Meno's thirty, lacks all of what makes the Meno a masterpiece-brilliant characterizations, philosophical depth, the irony, the sting-and begins with a didactic Socrates himself posing the reduced Meno-like alternatives for acquiring virtue. The omission of practice-along with so much else-strikes me as having little probative value. After noting points of interest in the dialogue for the history of later Platonism, Tarrant, Recollecting, 86-89, ultimately finds the dialogue itself "inimical to the spirit of Socratic inquiry" for similar reasons. For a more sympathetic reading of On Virtue, see M. Reuter, "Is Goodness Really a Gift from the Gods? Another Look at the Conclusion of Plato's Meno" ["Gift"], Phoenix 55 (2001): 77-97. Weiss, who devotes no separate consideration to practice in Weiss, Cave (but see note 57 below), endorses Scott's solution in R. Weiss, "Review of Dominic Scott, Plato's Meno," Bryn Mawr Classical Review 2006.12.30.

${ }^{16}$ Scott, Plato's Meno, 16 and 17n22; Daniel Devereux, "Nature and Teaching in Plato's Meno" ["Nature and Teaching"], Phronesis 23: 118-126, especially 123-124; Hoerber, "Plato's Meno," 83. O'Brien (Paradoxes, 107 and 140-48) sees their mutual exclusivity answered and reconciled in the Republic. DesJardins, "Virtue," finds an implicit reconciliation in the Meno itself. Guthrie (Sophists, 254) claims "it is not likely that anyone believed aretê to be attainable solely by the bounty of nature or by personal effort or by another's instruction”. However, Slings (Clitophon, 108) argues that Plato's contemporary and rival Isocrates-like Meno, a student of Gorgias-did view the three options as mutually exclusive.

PLATO, The electronic Journal of the International Plato Society, 12, 2012.

http://gramata.univ-paris1.fr/Plato/article117.html,

(C) All rights of reproduction of any form reserved. 
gods. ${ }^{17}$ Something arising naturally or supernaturally requires neither instruction nor practice. Examples not involving virtue can show why. A person born with normal color vision does not need to be told how to see red, and all the practice in the world won't make a person see red if she or he is born colorblind. Similarly, a supernatural gift such as clairvoyance is not (given an historical example such as Joan of Arc) something that is taught or trained, and might even be impaired by outside influences.

Turning to the other broad division, if virtue is something requiring effort to acquire, then (Meno's opening questions imply) one does so either by verbal instruction or by practice. If a subject is teachable, all the information essential to learning it can be conveyed by direct verbal means, as by a teacher to a student, whether by means of lectures or by some other form of instruction. Mathematical subjects provide a ready example (Socrates' exercise with the slave not withstanding; we shall consider it below). The teacher of geometry, for instance, can state explicitly all of the information a student needs to know: "Listen: I am about to define point, line, and plane"; or "Listen: I am about to state what is known as the Parallel Postulate."18

Finally, if virtue is acquired by some sort of practice, then verbal instruction alone is not sufficient. Skills like carpentry or the ability to play the piano (Aristotle uses cithara playing as his example in NE II 1) cannot be acquired simply by reading a book or hearing a lecture. Here a certain amount of verbal instruction may be helpful or necessary ("This is a scroll saw. Use it for making irregular cuts" or "This white key is called middle C. Position yourself in front of it"). But such instruction must be supplemented by the learner's doing the very things that the expert can do-actually making a scroll cut or playing a cithera or sonata. Something acquired through practice cannot be finally or fully achieved without engaging in appropriate forms of action or behavior that necessarily go beyond the verbal.

This last point is crucial. The verb askeo implies practices by which one forms oneself, as through the formation of the proper habits. Similarly, Meno's

\footnotetext{
${ }^{17}$ See also Protag. 323c. Both Scott, Plato's Meno, 158, and Weiss, Cave, 137-38, note that things bestowed by nature require no effort to acquire (see also Thompson, Meno, 161, citing Bury). One might say with $89 \mathrm{a}-\mathrm{c}$ in mind that the work comes later, in the effort to protect the naturally virtuous from corrupting influences. Tuche as a possible source of virtue can probably be assimilated to a theia moira as a supernatural source, but in any case is ruled out at 99a2-4. It is dismissed by Aristotle at NE I 9, cited above. Reuter, "Gift", 80-81, offers a rather different classification of the options.

${ }^{18}$ At Gorg. 450c7-e1, Plato has Socrates divide "all the crafts" into two groups in response to Gorgias' assertion that rhetoric is "about speeches." The first group is said to involve little or no speech to do its work. Painting and sculpture are the examples. Technai in the second group perform their work entirely through speech (dia logou pan perainousi). Arithmetic, logistikê, and geometry, Socrates says, rely on speech for all their activity and authority (pasa hê praxis kai to kuros; see also 451a8-c9, where astronomy replaces geometry). For more on this passage, see Dodds, Gorgias, 196-97.
}

PLATO, The electronic Journal of the International Plato Society, 12, 2012.

http://gramata.univ-paris1.fr/Plato/article117.html,

(C) All rights of reproduction of any form reserved. 
term askêton implies that which is fully achieved or mastered through practice. ${ }^{19}$ In a parallel vein, the verb paragignomai conveys the sense of being fully present or attained, or coming to full maturity, as with grain. Plato therefore intends Meno's question to be taken to ask for the sufficient condition by which aretê is fully and finally achieved, as opposed to asking for a list of necessary factors that may contribute in various degrees to its acquisition. This would help to explain why Plato has Meno imply that the options are mutually exclusive.

Given that there may be more than one necessary condition for something's attainment, it isn't surprising that there is often some overlap between instruction and practice: the piano teacher will want to make verbal comments, and the geometry student must do the homework. Nor would one want to deny that the "by nature" plays an important role in learning as wellone child has a natural aptitude for mathematics, another for music, and another for soccer or baseball. Nevertheless, there is an essential difference between what is didakton and what is askêton. The geometry teacher can simply point and say, "Look: you drew the wrong angle," or "Look: you wrote the wrong expression." The piano teacher, by contrast, must say both more and less: "Look: you keep missing that grace note. Try holding your wrist at a different angle," or "Look: Beethoven wrote molto cantabile. Try playing with more expression." The geometry teacher can say exactly what the correct angle or expression is, the piano teacher cannot. The piano student must learn for herself what it is by practicing. This implies two further points we shall consider in due course. First, the kind of practice that is necessary is in no way mindless. Second, everything that can be taught can be learned, but not everything that can be learned can be taught.

If all of this is correct, then the Meno's four options form a mutually exhaustive logical tree:

\footnotetext{
${ }^{19}$ For the sense of askêton, see Bluck, Plato's Meno, 203.
}

PLATO, The electronic Journal of the International Plato Society, 12, 2012. 


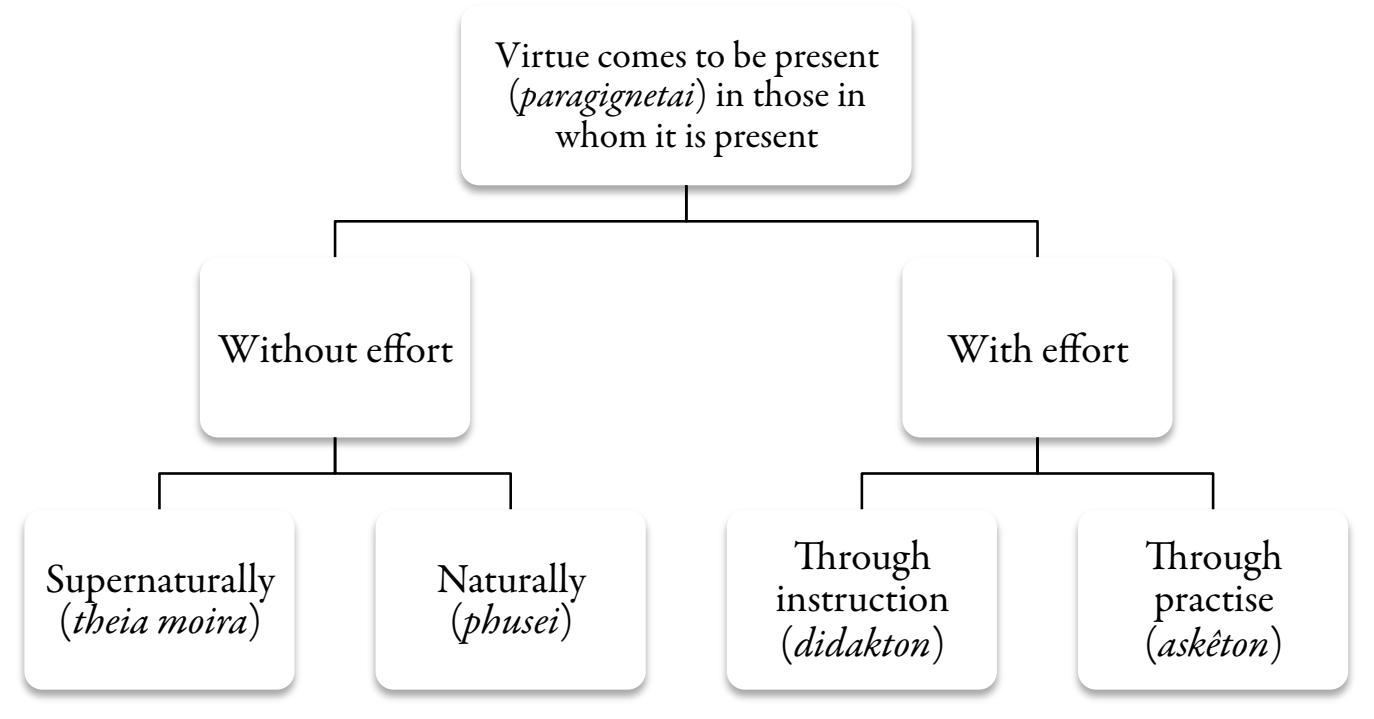

The distinction between teaching as verbal instruction and practice as essentially requiring mindful action beyond the verbal goes to the heart of whether virtue is teachable and raises larger questions of Socratic method and the precise nature of what is often called Socratic intellectualism. Pursuing these larger implications exceeds the scope of this paper, as does the question of Socratic practice in other dialogues. ${ }^{20}$ But keeping the distinctions in mind, we may turn to the two passages in the Meno that omit the option of practice. ${ }^{21}$

\footnotetext{
${ }^{20}$ Forms of askeo play a significant role in the Gorgias, and of course the nature and effectiveness of Socrates' practices figure in many dialogues. As one less familiar example: at Cleitophon 407b67, Cleitophon is made to contrast what is askêton with that which can be taught. Interestingly, Cleitophon omits askêsis a few lines later when he states categorically that Socrates maintains that virtue is teachable, even as he criticizes Socrates for not teaching him what virtue is; $408 \mathrm{~b} 7$.

${ }^{21}$ Under which of the four branches would anamnêsis fall? Recollection implies that at least some knowledge is innate relative to a soul's current incarnation. But if the definition of aretê is one of the items that can be recollected, this merely postpones the question of virtue's acquisition to an earlier point in the soul's existence, during which it "has seen" (eôrakuia) and "has learned" (memathêken; 81c6-7) all things, with no further description of the process involved. See further Tarrant, Recollecting, 39-43; Sharples, Meno, 148; Sallis, Being and Logos, 82-83; Klein, Commentary, 95. For an extended (and I think convincing) argument against the scholarly myth of a "theory" of recollection in Plato, see T. Ebert, "The Theory of Recollection in Plato's Meno," in Erler and Brisson (eds.), Gorgias-Menon, 184-198, and Weiss, Cave, 63-76.
}

PLATO, The electronic Journal of the International Plato Society, 12, 2012.

http://gramata.univ-paris1.fr/Plato/article117.html,

(C) All rights of reproduction of any form reserved. 
At the dialogue's end, Plato has Socrates raise and seem to endorse the idea that virtue comes to those who possess it as a divine allotment. Many commentators, finding no convincing alternative, conclude that this is Socrates' final considered position. ${ }^{22}$ In fact, what Plato has Socrates say is highly qualified and conditional. Plato gives all but one of the last twenty-eight lines of the dialogue to Socrates. For ease of reference, I shall break these lines into seven numbered sections:

SOCRATES: (1) If then (ei de nun), in the whole of this discussion (en panti tô( $(i) \log \hat{o}(i)$ toutô( $(i))$ we have sought and spoken well (kalôs ezêtêsamen kai elegomen), virtue would be neither by nature nor something teachable, but something that has come to be present (paragignomenê) through a divine allotment (theia moira) without intelligence (aneu nou) in those in whom it is present (paragignêtai) - (2) unless (ei $m \hat{e})$ some one of the politic men were such that he could make (poiêsai) another politic as well. ${ }^{23}$ (3) If there were, one could almost say that such a man would be among the living what Homer said Teiresias was among the dead, that "he alone of those in Hades understands (pepnutai), while the rest are fluttering shadows." In the same way would such a man be here, a true thing among shadows with regard to virtue.

MENO: (4) You seem to me to speak very well (kallista dokeîs moi legein), Socrates.

SOCRATES: (5) From this reasoning, then (ek men toinun

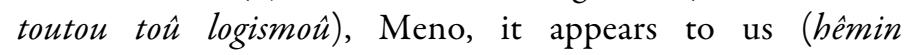
phainetai) that it is by divine allotment that virtue comes to be present (paragignomenê) in those in whom it is present (paragignetai). (6) But (de) we will know the clear truth (to saphes) about this when, before seeking in whatever way virtue comes to be present (paragignetai) in human beings, we first make the attempt to seek (epicheirêsômen zetein)

${ }^{22}$ See further Scott, Plato's Meno, 192-193, and Devereux, "Nature and Teaching," 124. Recently P. Dimas, "Teachers of Virtue" ["Teachers"], Ancient Philosophy 27 (2007): 1-23, has argued that Socrates regards virtue as a "gift of the gods [representing] a necessary steppingstone in one's ascent toward the knowledge that comprises virtue" (p. 22), but that this knowledge is not presently known to anyone, including Socrates (Dimas does not say whether he thinks Plato knows what virtue is). Michael Forster, "Socrates' Profession of Ignorance" ["Profession"], Oxford Studies in Ancient Philosophy 32 (2007): 1-35, argues that the historical Socrates believed that virtue was true belief obtained through divine inspiration, and cites the conclusion of the Meno as part of his evidence. Coming at the question from the perspective of later Academic debates, Reuter, "Gift”, explains the Meno's conclusion as expressing the Platonic position that good men come to rule their cities through an act of divine providence.

${ }^{23} \mathrm{My}$ rendering of this last phrase closely follows the translation of Anastaplo and Berns.

PLATO, The electronic Journal of the International Plato Society, 12, 2012.

http://gramata.univ-paris1.fr/Plato/article117.html,

(c) All rights of reproduction of any form reserved. 
what virtue is in itself. (7) But now it's time for me to go somewhere. You persuade your host Anytus of the same things you've been persuaded of, so that he may be more gentle (pra(i)oteros). For if you do persuade him, you will also benefit the Athenians. (99e4-100c2)

Rather than closing with anything like a straightforward endorsement of virtue as a theia moira, Plato ends the Meno with a remarkable-but largely unremarkedseries of qualifications. ${ }^{24}$ The if $(e i)$ at the start of $(1)$ is obvious but crucialstarting with the conclusion's first word, Plato makes everything that follows conditional (a qualification reinforced by the 'unless' that begins (2) and the "If there were" at the start of (3)). The mindless quality of the divine gift should also put us on our guard: such virtue is aneu nou, just as was the inferior demotic virtue identified in the Phaedo and Republic. ${ }^{25}$ Most importantly, by having Socrates refer to "the whole of this discussion," Plato prompts the reader to recall the entire dialogue. In doing so, he takes the reader back to Meno's opening three options - as does the repetition throughout the passage of forms of paragignomai, the verb used at 70a3 when Meno first asked how virtue is acquired. ${ }^{26}$

This makes conspicuous a gap in Socrates' summary of the "whole discussion." Plato has Socrates name only two of the three ways in which virtue might be acquired, by teaching and by nature. Plato asks that the whole inquiry be recalled, but anyone who does so would immediately notice that Plato's Socrates omits practice.

In fact, not everyone would notice. Meno does not notice. This, I take it, is the point of (4), the last speech Meno is given in the dialogue. Socrates had said, "if we have ... spoken well (kaloss)" in saying that virtue is acquired neither by teaching nor by nature. Plato has Meno answer with the superlative: "You seem to me speak very well (kallista)." Meno's dialectical gifts are clearly limited, so one might be tempted to follow Hoerber in saying "any further reasoning would be beyond his ken." Plato has shown at least twice that Meno's endorsement of a

${ }^{24}$ The qualifications are noted by Scott, Plato's Meno, 4; T. Brickhouse and N. Smith, Plato's Socrates (Oxford: Oxford University Press, 1994), 57-58; Day, Meno in Focus, 31; O’Brien, Paradoxes, 95. They are highlighted by Tarrant, Recollection, 72-75; Reuter, "Gift", 93-94; Sallis, Being and Logos, 101-103 (in connection with the "curious" conclusion that virtue is a divine gift); and Klein, Commentary, 255-56.

25 The mindlessness of such god-given virtue is emphasized by Klein, Commentary, 255-56, and Bluck, Plato's Meno, 434-36. Reuter, "Gift", offers another explanation; see esp. pp. 87-89. Both he and Tarrant, Recollection, show that the later Platonic tradition took divine allotment or portion very seriously. I do so as well, provided that practice is recognized as needed for the "cultivation and development" (Reuter, "Gift", 94) of this gift if virtue is to be fully attained.

${ }^{26}$ Even if one takes "the whole of this discussion" to refer back only to the announcement of the hypothetical method $(86 \mathrm{c} 8-\mathrm{d} 2)$ and the ensuing examination of the hypothesis that virtue is teachable, we shall see how the lead-in to that passage already points the reader back to Meno's opening questions.

PLATO, The electronic Journal of the International Plato Society, 12, 2012.

http://gramata.univ-paris1.fr/Plato/article117.html,

(C) All rights of reproduction of any form reserved. 
conclusion should not be taken at face value. The first is his misplaced enthusiasm for the mock Gorgianic definition of color at 76d. The second is his exclaiming at $89 \mathrm{a} 4-5$ (see also c7) that the claim that virtue is teachable is a kalos answer. That said, Meno's final line is correct as far as it goes: the dialogue has shown that neither teaching nor nature is sufficient to make one virtuous. ${ }^{27}$ But blaming a character in a fictional dialogue misses the point. It is Plato who makes Meno overlook the omission of his own second option.

Why would Plato do that? Before answering that question-and it is the crucial question-we should notice two final qualifications. The conditional endorsement of the divine allotment is again underlined in (5), which begins: "From this reasoning, then, it appears to us...." In other words, if virtue is neither a natural endowment nor teachable, it would seem to be a divine gift. But the conclusion is valid only if all other mutually exhaustive options have been ruled out.

The final qualification is expressed in (6). With a de-clause at $100 \mathrm{~b} 4$ answering the conditional men at $100 \mathrm{~b} 2$ at the start of (5), Plato tells the reader that, however it might appear, the truth (to saphes) is not yet known. Socrates' call that they jointly seek (zêtein; 100b7) for what virtue is strongly suggests they did not do as well in what they had sought and said (99e4-5) as Meno supposed. Plato has Socrates insist (as he is made to do as well at the end of the Protagoras) that until virtue itself has been defined, a search for how it is acquired will be premature-a caution, let us note, as applicable to the final suggestion that virtue comes as a mindless theia moira as to the two options that have been explicitly ruled out. Though similar pleas to start over and return to the beginning are fairly common in the aporetic dialogues, Socrates' words in this context again serve to remind the attentive reader that not all the options posed at the dialogue's beginning have been explored.

The dialogue concludes with (7). On a vague pretext of having business elsewhere $(p o i ; 100 \mathrm{~b} 8)$, Plato has Socrates instruct Meno to try to persuade Anytus of what he himself has just been persuaded of so as to make him more gentle (pra(i)oteros) and thus benefit the city. We needn't wonder at the outcome of that unwritten dialogue.

Meno's likely failure at persuading Anytus of anything is more than a sly joke at his expense. ${ }^{28}$ If, contrary to all expectations, Meno were to make Anytus more gentle, he would succeed, to some degree at least, at what the Sophists promised: by making Anytus more gentle, he would begin to make him more virtuous. To see why we must ask how Meno would go about making Anytus gentler. How, for Plato, would anyone do so? In its general form, the question is easily answered. For Plato, a person can be made gentler by being refuted. This is

\footnotetext{
${ }^{27}$ Hoerber, "Plato’s Meno,” 91.

${ }^{28}$ Just as it is more than a reflection of Plato's pessimism, though it is that as well; see Scott, Plato's Meno, 216-218, and Gordon, Turning, 113-15.
}

PLATO, The electronic Journal of the International Plato Society, 12, 2012.

http://gramata.univ-paris1.fr/Plato/article117.html,

(C) All rights of reproduction of any form reserved. 
the lesson Plato has Socrates deliver (without qualifications!) at the end of the Theaetetus: "But if you remain barren [after our present inquiry], you will be less coarse (barus) toward your associates and gentler (hêmeteros), modestly (sôphronôs) not supposing yourself to know what you do not know" (Tht.210c24). ${ }^{29}$ It is the special benefit conferred by the so-called Sophist of noble lineage, when Socrates compares an ordinary Sophist and the noble Sophist by contrasting a wolf to a dog, the wildest (agriôtaton) to the gentlest (hêmerôtatô( $i$ ) (Sophist 229e-231b). Being refuted has the potential to transform a belligerent opponent into a cooperative, or at least a non-oppositional, partner in inquiry (Republic I, 354a12; see also Rep. VI, 501e7-502a2; IX, 589c6-590d1). This is why the reader suspects Meno would fail. Though he seems to show some signs of gentleness by the end of the dialogue (a point we'll return to shortly), as expressed in (2) a person must be politic to make another so, which is to say, a person must be virtuous to instill virtue in another. ${ }^{30}$

Is Socrates the Teiresias-like politic man spoken of in (3) who by refuting others may make them more virtuous and so benefit the city? ${ }^{31}$ This is a profound and essential question for any reader of the dialogues. In several dialogues-the Gorgias, the Apology, the Meno itself-Plato shows Socrates achieving practically the opposite result. Against the rare success of a Theaetetus stand Callicles, Charmides and Critias, Anytus, the Athenian jury, and the many nameless poets, politicians, and craftsmen stung by this ironic gadfly, who are reduced to an angry and resentful malevolence intimating violence. Why Plato shows Socrates humbling and gentling a few but antagonizing so many goes to the heart of Plato's depiction of and possibly changing attitude toward his teacher, and may lie behind his own decision not to philosophize in the agora but to found a learned community and write dialogues that afford the reader an insulating critical distance that a live interlocutor lacked. ${ }^{32}$ Perplexity and aporia are naturally frustrating, so perhaps a natural or supernaturally endowed disposition toward virtue is a necessary condition for its acquisition after all. All that being said, Socrates is praised as pra(i)otaton at Phd. 116c5, and at Gorgias 521d6-8 Plato has Socrates call himself the only Athenian engaged in the true

\footnotetext{
${ }^{29}$ Hoerber, "Plato's Meno," underlines the many parallels between the Meno and the Theaetetus. At NE II 1, 1103b18-19, Aristotle implies that a person becomes sophrôn and gentle (praos) simultaneously; see also I 13, $1103 \mathrm{a} 8$.

${ }^{30}$ Commenting on a different passage, Scott, Plato's Meno, 144, writes: “A true teacher is someone capable of making another like himself, i.e. knowledgeable or, in the context of the Meno, virtuous."

${ }^{31}$ For an extended discussion of the identification of Socrates with Teiresias, see Dominic Scott, Recollection and Experience: Plato's Theory of Learning and Its Successors (Cambridge: Cambridge University Press, 1995), 48-50. See also the brief but suggestive comments of Reuter, "Gift," 89, Weiss, Cave, 169; and Sternfeld and Zyskind, Acquisitive, 104.

32 I thank Marina McCoy for insightful comments prompting much of what I say in this paragraph.
}

PLATO, The electronic Journal of the International Plato Society, 12, 2012.

http://gramata.univ-paris1.fr/Plato/article117.html,

(C) All rights of reproduction of any form reserved. 
political art. But one must be precise here. Plato at Meno 100a1-2 does not write that there may be a politic person able to teach another to be politic. ${ }^{33}$

When the thrice-refuted Meno compares Socrates to a stingray, he begins by saying, "You do nothing but make yourself perplexed and make others perplexed as well" (tous allous poieis aporein; 80a1-2). ${ }^{34}$ Plato doesn't allow Meno to realize the full significance of what he is saying. In his third and final attempt to define aretê, Meno was made to say that virtue was the ability to obtain (porizesthai) good things, which for Meno include gold, silver, and possessions (78c5; also c1). Plato has Socrates force Meno to admit that obtaining possessions must involve justice or self-control or piety if the way (poros) is to qualify as virtuous. If it does not, he continues, then the 'not-getting'-the $a$ poria - is virtue when getting would be unjust. And so, Plato has Socrates ask, "Isn't this also virtue, the not-finding-a-way (ouk aretê kai autê estin, hê aporia)?" (78e5). Meno is correct to say that Socrates is perplexed and makes others perplexed as well. What Plato doesn't allow Meno to realize (at least before the geometry lesson) is that by inducing perplexity, Socrates benefits others and offers them an opportunity to become more virtuous. ${ }^{35}$ This yields a pleasingly Socratic paradox: the way (poros) to virtue is a-poria.

Does Meno benefit from his own Socratically induced aporia? That, in essence, is what Socrates' final charge to Meno would assess. Plato repeatedly draws attention to the character defects of Socrates' interlocutor in the first third of the dialogue-Meno is over-confident (72a2-3), wanting to be told ( $73 \mathrm{c} 8$, $75 \mathrm{~b} 1,81 \mathrm{a} 7)$, argumentative (75c9), arrogant and demanding (76a8-10, 76b5-7, $76 \mathrm{c} 3)$, careless and inattentive (79a11-12), vain and preening (80b1-4, c3-5)..$^{36}$ Whether and how much Meno changes by the dialogue's end have long been a matter of scholarly contention, but even the most generous assessment finds

\footnotetext{
${ }^{33}$ In contrast to what is implied by Scott, Plato's Meno, 216-17; Reuter, “Gift”, 89; Sharples, Meno, 14 (see also 189); and Wilkes, "Conclusions." See further Gordon, Turning, 113, and Bluck, Plato's Meno, 43. Plato consistently uses poiein rather than didaskein in connection with Socratic activities in the Meno. Thus, the Tieresias figure "could make" (poiêsai; 100a2 ) others more politic. See further note 56 below.

${ }^{34}$ Plato twice has Socrates confess his own aporia at the beginning of the dialogue (71b1-2 and $72 \mathrm{a} 2)$, in contrast to Meno's confidence that there is no aporia in stating what virtue is (72a3). See also Laches 200e2-5. For the extent of Socrates' own aporia, see Matthews, Perplexity, chapters 3 and 4, and note his wonderful subtitle for chapter 5 dealing with the first half of the Meno: "The Self-Stinging Stingray." If askêsis implies self-formation as suggested above, then Socrates's practice of perplexing others and himself would be consistent with this sense of the word.

${ }^{35}$ See also Sharples, Meno, 140; Klein, Commentary, 79. I thank Shane Ewegen for a stimulating discussion of this passage.

36 The moral defects of Meno's character are emphasized by Weiss, Cave, 17-21; Gordon, Turning, 95-103; Klein, Commentary, 35-38.
}

PLATO, The electronic Journal of the International Plato Society, 12, 2012.

http://gramata.univ-paris1.fr/Plato/article117.html,

(C) All rights of reproduction of any form reserved. 
relatively modest and probably unsustainable improvement. ${ }^{37}$ But the question that should be asked is this: why doesn't Plato show Meno making more progress during the dialogue as a result of his perplexity? If Plato intended the Meno to serve as an exhibition of Socratic moral education (as he surely did), ${ }^{38}$ his decision to allow the dialogue to end in apparent failure requires an explanation.

No answer to the question can ignore Plato's choice of Meno as Socrates' interlocutor. The historical Meno's downfall is documented by Xenophon (Anabasis 2.1.5, 2.2.1, 2.5.28-31, 2.6.21.29). According to Xenophon (who, it should be noted, is far from impartial), Meno was greedy and grasping and lacking in scruples-qualities Plato may be evoking in the discussion at 78c-e. In what Plato's original audience must have caught as a choice bit of black humor, the man whom Socrates calls the "hereditary guest-friend of the Great King" $(78 \mathrm{~d} 2-3)$ traveled to Persia in 401 as a mercenary, where he suffered a terrible death at the King's hands. ${ }^{39}$ Whatever benefit the historical Meno might have derived from the real Socrates would have been short-lived.

Better evidence for judging the improvement of Meno's character-by which I mean evidence internal to the Meno-comes from Plato's careful plotting of the dialogue. We should begin by noticing that Plato delays revealing Meno's full response to his own aporia for more than six Stephanus pages. As Meno's third attempt to define virtue breaks down, Plato has Socrates repeatedly urge Meno to return to the beginning (palin ex archês; 79c3-4, 79e1-2, 79e5). Instead of doing so, Meno is made to give voice to what many an interlocutor-not to say reader-has felt through his comparison with the stingray and the paradox of the learner (79e7-81d9), though even here, Socrates develops the formal paradox out of implications Plato has made Meno too indolent to recognize. ${ }^{40}$ After agreeing to show (epideixomai; 82b2) Meno that learning is recollection and not teaching, Socrates leads one of Meno's attendant slaves into a state of aporia over how to construct a square double the area of a given square. ${ }^{41}$ He forces the slave to admit he does not know how to solve the problem, even though he initially thought he did know (84a3-4). Plato has Socrates ask Meno to reflect on what he

\footnotetext{
${ }^{37}$ The question is widely debated. Among those who see an improvement in Meno are Scott, Plato's Meno, 209-213; Gordon 1999, 93-116; and Sternfeld and Zyskind, Acquisitive, 8-18. Nehamas is sympathetic towards Meno from the start. Those who deny any significant change include Weiss, Cave, 129-30; Sallis, Being and Logos, 94-95; Klein, Commentary, 184; and W. K. C. Guthrie, Plato: Protagoras and Meno (Harmondsworth: Penguin Books, 1956), 11.

38 Scott, Plato's Meno, 5-6. See also Christopher J. Rowe, Plato and the Art of Philosophical Writing $[$ Art $]$ (Cambridge: Cambridge University Press, 2007), 131-132.

${ }^{39}$ I thank John Lewis for a stimulating discussion of Plato's humor.

40 Sallis, Being and Logos, 77-78, nicely connects the need for Socrates to do so to Meno's paradoxical "complex of ignorance and memory."

${ }^{41}$ On the appropriateness of epideixis in relation to recollection at this point, see Sallis, Being and Logos, 91-93.
}

PLATO, The electronic Journal of the International Plato Society, 12, 2012.

http://gramata.univ-paris1.fr/Plato/article117.html,

(C) All rights of reproduction of any form reserved. 
has just witnessed. Won't Meno admit the slave is better off (beltion echei) because of his perplexity (84b4-5)? Meno concedes that by making him perplexed, Socrates has done something useful (prourgon ti; 84b10). Only now, Socrates says, may the slave make progress, starting from this very perplexity and engaging in a joint inquiry (84c11-12).

It is important not to overstate the slave's progress. The slave's cognitive state remains as if in a dream, suggesting that little if anything of what he has recollected would count as knowledge. Much additional effort is required-in this life-before knowledge is obtained. ${ }^{42}$ But perhaps because the slave has been shown a way (poros) forward - that he can learn without being taught-he seems willing to make that effort. Plato at least gives no hint of any lingering frustration. And so Plato ends the episode by having Socrates insist that perplexity benefits a person not just intellectually but morally as well:

SOCRATES: As for the other points, I would not altogether insist on my argument [in favor of recollection]. But that by believing one ought to search for what one does not know we would be better, more courageous, and less lazy than if we supposed we were neither able to discover nor ought to seek what we do not know-for that I would certainly do battle, as far as I am able, in both word and deed. $(86 \mathrm{~b} 6-\mathrm{c} 3)^{43}$

Only at this point, after having Socrates emphasize the moral benefits of perplexity, does Plato reveal Meno's full response to his own aporia. In what counts as the second important passage in which the option of practice is conspicuously missing, Plato has Socrates invite Meno (once again) to join him in a cooperative search:

SOCRATES: Are you willing, then, since we agree that one ought to search for what one doesn't know, to try to search in common (epicheirêsômen koinê( $(i)$ zetein) for what virtue is?

MENO: By all means (panu men oun). But then again (ou mentoi), Socrates, I would most enjoy (hêdista) what I asked in the first place (to prôton), to examine and hear whether it's necessary to make the attempt as its being something teachable (hôs didakô(i)), or as by nature (hôs phusei), or as in

\footnotetext{
${ }^{42}$ See also Ebert, "Recollection," 193; Rowe, Art, 133-34; Nehamas, "Socrates as Teacher," 21-22.

${ }^{43}$ See also Halper, "Lesson," 234: "the epistemic doctrine is also an ethical doctrine"; Weiss, Cave, 69; Gonzalez, Dialectic, 166; Wilkes, "Conclusions," 215, 216-17. For Klein (Commentary, 201), this speech is proof of Socrates' own moral aretê. By contrast, Scott, Plato's Meno, 123, reads the passage as referring to a derivative sort of manliness in the intellectual sphere. While in the immediate context this may be correct, one should not forget Socrates' own exemplary courage as reported by Alcibiades in the Symposium nor overlook the strong connection between true courage (again exemplified by Socrates at Delium) and perplexity drawn in the Laches.
}

PLATO, The electronic Journal of the International Plato Society, 12, 2012.

http://gramata.univ-paris1.fr/Plato/article117.html,

(c) All rights of reproduction of any form reserved. 
whatever way (hôs tini pote tropô) virtue comes to be present (paragignomenês) in human beings?

SOCRATES: If I were master (êrchon), Meno, not only of myself but also of you, we wouldn't examine whether virtue is teachable or not teachable before we had first sought for what it is itself. But since you don't at all attempt to master yourself (sautôu oud' epicheireis archein) - so that you might be free-but instead attempt to be my master-and you do master me-I will submit to you. For what can I do? So it seems it's necessary to consider what sort of a thing something is when we don't yet know what it is. (86c5-e2)

In this exchange, Plato shows the reader that Meno will not change, and shows why. Like the slave, Meno at first seems willing to join in a cooperative inquiry (panu men oun, duplicating exactly the slave's words at 85b7). But he quickly falls back into old habits. He would rather enjoy (hêdista; cp. Gorg. 521d9-e1) hearing Socrates answer what Plato has him call his original question: is virtue acquired (paragignomenês) by teaching, by nature, or some other way? ${ }^{44}$ As at the dialogue's end, Meno is made to forget practice, the very thing Meno needs to develop the self-control he lacks. ${ }^{45}$ Plato immediately has Socrates chastise him for the lack of self-control his insistence reveals: Meno seeks to rule over others instead of trying to master himself. Nevertheless, Plato has Socrates submit. ${ }^{46}$

In his aggressive, tell-or-be-told behavior, Meno reveals habits acquired from his teacher Gorgias. As is widely recognized, Plato uses Meno throughout the dialogue as a representative product of Gorgias's particular kind of education (71c9-d3, 73c6-8, 96d5-7). This may be seen as early as Meno's opening barrage of questions, which have been likened to the style of Gorgias. ${ }^{47}$ If what Aristotle says about Gorgias at Pol. 1260a24-28 is true, Plato may intend Meno's swarm of virtues to reflect Gorgias's approach to definition through enumeration. An

\footnotetext{
${ }^{44}$ On Meno's conflating an active joint investigation with passively hearing someone else's opinion, see Weiss, Cave, $51 \mathrm{n}$ 9 and $127 \mathrm{n} 1$. I take the conflation as evidence against Gordon's argument that Meno has grasped the need for an active, joint inquiry coming out of the geometry lesson - though of course the reader may be meant to draw this lesson.

${ }^{45}$ See also Anastaplo and Berns, Plato's Meno, 51-52; Weiss, Cave, 128n3; Klein, Commentary, 184-85.

${ }^{46}$ I take Socrates' statement at $87 \mathrm{~b} 9$ that it makes no difference whether one says 'teachable' or 'is recollected' to be part of his submission to Meno announced at $86 \mathrm{~d} 8$ and thus Plato's way of alerting the reader to the limitations of what is to follow, rather than a pointer to a special kind of 'maieutic' teaching equivalent to recollection. See also Weiss, Cave, 128-130; Wilkes, "Conclusions", 212-13; Sallis, Being and Logos, 96-98; Klein, Commentary, 182-89. For the maieutic reading, see Scott, Plato's Meno, 144; Sharples, Meno, 162; Bluck, Plato's Meno, 20-22, 325-326.

${ }^{47}$ Gordon, Turning, 101; Nehamas, "Socrates as Teacher," 2; Sternfeld and Zyskind, Acquisitive, 8.
}

PLATO, The electronic Journal of the International Plato Society, 12, 2012.

http://gramata.univ-paris1.fr/Plato/article117.html,

(c) All rights of reproduction of any form reserved. 
obvious instance is Meno's preference for the puffed up Gorgianic definition of color, which Socrates says is the kind of answer to which he has been habituated (sunêtheion; 76c4-d8). ${ }^{48}$ Another is Meno's parroting of Gorgias's definition of virtue as the power to rule over others, first offered at $73 \mathrm{c} 9-\mathrm{d} 1$ and alluded to by Socrates at $86 \mathrm{~d} 7$ in the passage just quoted (at Gorg. $452 \mathrm{~d}$-e, Gorgias says that the persuasion oratory provides gives one the power to rule over others and enables one to be free). The learner's paradox, which Socrates calls eristic (80e2), probably reflects Gorgias's fondness for skeptical and contentious argument, just as Meno's general manner in the first third of the dialogue reflects the essentially competitive rather than cooperative nature of Gorgias's craft. ${ }^{49}$

A telling passage follows Meno's failed first attempt at definition and anticipates Socrates' submission to Meno at 86e. At 75a8-9, Plato has Socrates propose that, before defining virtue, Meno define shape and color "for practice" (meletê). But Meno, habituated as he is by a teacher who promised to deliver an answer to every question, refuses: "No, Socrates, you do it." Here too Plato has Socrates chide him, saying that their conversation should display a gentler (pra(i)oteron) form than a disputatious encounter would (75d2-4). But already Plato has Socrates yield..$^{50}$

An often overlooked passage at the beginning of the dialogue sets Meno's Gorgias-derived habits as a frame for everything that follows. Instead of having Socrates respond directly to Meno's opening barrage of questions, Plato has him divert the discussion by lavishing ironic praise on Meno and his fellow Thessalians. It used to be, Socrates says, that Meno's countrymen were reputed for their wealth and horsemanship (traditional marks of aristocratic arête, recalling Meno's noble birth and connections; 71b6-7). But since Gorgias came to be among them, they are admired for wisdom (sophia) as well. Gorgias, Socrates says, has "habituated you in the habit" (ethos umâs ethiken) of answering questions boldly and authoritatively, in a manner proper to experts (70b6-c1), no doubt reflected in Meno's report that he has given countless speeches on the topic of acquiring virtue (80b2-3). ${ }^{51}$ The ensuing dialogue shows the poverty of such

\footnotetext{
${ }^{48}$ See further Gordon Turning, 100 on Plato's punning use of poroi and aporrai throughout this exchange. Ebert, "Recollection", 196-97 finds a similar example in Meno's approval of Socrates' high-flown rhetoric at 86b1-5.

${ }^{49}$ See Aristotle, Soph. El. 34, 183b36-38; DK 82B3. At Gorg. 456b6-457b5, Plato has Gorgias repeatedly characterize his craft as a competitive art (agonia). See also Sharples, Meno, 142-143; Weiss, Cave, 52; Klein, Commentary, 62n21 and 88; Hoerber, "Plato's Meno," 101. Though he has Socrates call it eristic, Plato clearly takes the paradox seriously in the Meno. See further Nehamas, "Socrates as Teacher," 8-9.
${ }^{50}$ See also Hipp. Minor 364d2; Soph. 217d1-3. Scott notes the reference to practice, but citing his earlier argument in favor of manuscript F, says it would be incongruous for Socrates to mention practice here but no place later.
${ }^{51}$ See also Anastaplo and Berns, Plato's Meno, 48; Tarrant, Recollecting, 24; Gordon, Turning, 96- 97; Sallis, Being and Logos, 67n3; Klein, Commentary, 41.


habits.

A final example of Meno's counter-productive habits emerges from a more extensive passage immediately prior to the episode with the slave and prefigures Meno's failure to join in a genuinely cooperative investigation. Just after having Socrates claim that all learning is recollection and that a person should be courageous in searching for knowledge, Plato has Socrates ask Meno if he is willing to take part in a cooperative search for the meaning of aretê (as he had already asked Meno to do at $80 \mathrm{~d} 3-4)$ :

SOCRATES: One must not, then, be persuaded by the eristic argument $(t \hat{o}(i)$ eristikô(i) logôo(i)); for it would make us lazy (argous) and sounds pleasing (hêdus) to men who are soft (tois malakois). But this one [recollection] makes us hard working and ready to seek (zêtêtikos). Trusting in this to be true, I am willing to seek with you for what virtue is.

MENO: Yes, Socrates. But how do you mean this, that we do not learn, but that what we call learning (mathêsis) is recollection? Can you teach me (didaxai) how this is so?

SOCRATES: And after I just said, Meno, that you are capable of anything (panourgos; cp. 80b8), you are now asking if I can teach you, I who say that it is not teaching, but rather recollection-so that I would immediately be shown to be contradicting myself.

MENO: No, by Zeus, Socrates, I didn't speak looking for that to happen, but just out of habit (bupo tou ethous). But if you can show me (endeizasthai) in any way that it is as you say, do show me (endeizai).

SOCRATES: Well, though it isn't easy, I'm willing to make the effort for your sake. (81d5-82a8)

This exchange precisely mirrors the passage at $86 \mathrm{c}-\mathrm{e}$ omitting practice, and with it forms a pair of bookends around the geometry lesson. Both passages start with a request by Socrates for a cooperative inquiry, and cite similar moral benefits to be derived from doing so. In both, Meno offers a quick initial agreement. But in both, Meno immediately diverts the discussion to something he would find more pleasant. Socrates chides Meno in both cases for his willfulness, but in both Plato has him quickly submit.

The difference in the present passage comes when Meno asks Socrates to explain the idea that all learning is recollection. Meno asks "Can you teach me how this is so?" (81e5). When Socrates accuses Meno of trying to trap him in a contradiction, Plato has Meno apologize, making him say that he was only speaking "out of habit" (bupo tou ethous; 82a5). To say that Meno did not intend

PLATO, The electronic Journal of the International Plato Society, 12, 2012.

http://gramata.univ-paris1.fr/Plato/article117.html,

(c) All rights of reproduction of any form reserved. 
to trap Socrates misses Plato's point. ${ }^{52}$ Even if we imagine a red-faced Meno apologizing to Socrates, the young interlocutor still does not do what Socrates had asked. Instead of joining in a cooperative search, Plato has Meno ask Socrates to "show" him in some way (pôs endeixasthai) what he means. In other words, the sophistically trained young man wants to hear a sophistically styled exposition. Meno's long-inculcated preference for sophistic epideixeis (82b2) must be indulged..$^{53}$

Meno typifies the view that everything that can be learned can be taught (and received passively). Already in the opening lines of the dialogue Meno conflates teaching and learning, when Plato has him substitute mathêton for didakton. The same conflation can be seen in the passage where virtue as a natural endowment is ruled out (89c4), when Plato has Meno substitute didakton for Socrates' mathêton, again forgetting the option of practice. We shouldn't be surprised, then, when Meno falls back into old habits after the geometry lesson and demands that Socrates return to his opening question, even as he forgets to include the option of practice.

Having Meno forget what he had previously said seems to be one way Plato exploits the irony of Meno's name, which is related to memory and remembering. ${ }^{54}$ In one sense, Meno has a good memory (a quality often remarked on in the literature), having memorized various answers taught to him by Gorgias, and probably questions such as those in his opening barrage as well. ${ }^{55}$ But Plato has Socrates remark that the ability to learn and having a good memory (eumathia kai mnêmê; 88a9) is beneficial only when guided by phronesis (88b4) and used with intelligence (meta nou; 88b7); otherwise, he says, they are harmful. Plato uses Meno's spotty ability to remember his own original three options to illustrate a soul that has learned and been trained (manthanomena kai katartuomena) without intelligence (aneu nou; 88b7-8) and so is harmed by it.

Plato's Meno cannot define virtue because of the habits he has formed, unreflective habits of mind and character unguided by phronesis or nous. His failing is intellectual in that Plato has him indulge uncurious habits of answering confidently when he does not know, of relying on answers from others and lazily demanding to be told, of forgetting what he himself had said. It is a moral failing in that he lacks the andreia to pursue hard questions instead of pleasant answers,

\footnotetext{
${ }^{52}$ Meno's lapse is excused in this way by both Weiss, Cave, 78n2, and Klein, Commentary, 96; see also Gonzalez, Dialectic, 166. Contrast my pairing of the two passages with the deflationary reading of Scott, Plato's Meno, 122-125.

${ }^{53}$ Also noted by Gonzalez, Dialectic, 172.

${ }^{54}$ For Plato's punning on Meno's name, see Weiss, Cave, 19n8; and Klein, Commentary, 43-46. On Meno's memory as a source of his ignorance, see Sallis, Being and Logos, 67-68, 75-76.

55 Aristotle reports at Soph. El. 34, 183b36-184a1, that Gorgias made his pupils memorize both answers and questions designed to lead the respondent into refutations. See also Sharples, Meno, 137-138; Klein, Commentary, 71-72.
}

PLATO, The electronic Journal of the International Plato Society, 12, 2012.

http://gramata.univ-paris1.fr/Plato/article117.html,

(C) All rights of reproduction of any form reserved. 
and the self-control to make himself change. Meno first seeks to defeat Socrates by repeating what he has memorized from Gorgias; soon, he demands new answers from Socrates in place of those he has been forced to abandon; eventually he attacks Socrates for his own perplexity. What he will not do is take full part in a joint inquiry. Instead, Plato has him force what should have been a shared investigation back into the channel he first laid out without recalling precisely what he had originally said, bullying into submission the one man capable of stinging him out of his complacency. Plato's Meno is doomed, not just as an intellectual inquirer, but as a moral agent as well.

This is the philosophical point behind Plato's having Meno forget practice as a means of acquiring virtue. Virtue cannot be taught. But it can be learned through the appropriate kind of practice. No doubt, practice includes (as it does in Aristotle) the repetition of right actions leading to habituation (cf. $N E$ II.1, 1103a14-1103b25). Many of Meno's bad habits and consequent behaviors-his laziness and lack of intellectual courage, his deficient self-control and general mindlessness - may be attributed to the lack of this sort of practice, even as they show the deficiencies of the habits inculcated in him by Gorgias. But at a deeper (or perhaps we could say, more Platonic) level the Meno points to the need for a kind of practice that involves prolonged submission to the perplexity provoked by Socratic questioning. This is the practice of Socratic philosophizing as a way of life. In his own way, the character Meno is allowed to express this. Plato has him speak more truly than he knows when he describes Socrates as the one who makes others perplexed and is always perplexed himself. Plato implies that only through prolonged association (sunousia) with a truly politic man will the hit-or-miss "virtue" that operates aneu nou be replaced with a mindful wisdom, the phronesis meta nou at the core of all the other virtues.

Perhaps this is Plato's real point in quoting the first of the two passages from Theognis (95d5-e2), urging the young person to spend time in the company of noble men, especially given that the second passage (95e6-96a2) denies that virtue can be taught. A passage from the Gorgias also suggests the need for sustained contact. That dialogue ends with Socrates urging Callicles to practice virtue (askôn aretên), turning to politics only after practicing it in common with him $(k o i n e \hat{(}(i)$ askêsantes; $527 \mathrm{~d} 1-4)$. The best life is to "practice justice and the rest of the virtues" (dikaiosunên kai tên allên aretên askountas; 527e4; see also $509 \mathrm{~d} 8$-e2) with the one true practitioner of the political art. The importance of extended sunousia with Socrates is the non-metaphorical point of the midwife passage in the Theaetetus (see especially Tht. 150d2-151a5). Surely this is the life exemplified by Socrates' sustained examination of himself and others. ${ }^{56}$

\footnotetext{
${ }^{56}$ Sunousia is a central theme of Kenneth M. Sayre, Plato's Literary Garden [Garden], University of Notre Dame Press, 1995. Another author of Socratic dialogues, Aeschines, gives the following words to Socrates in his Alcibiades: "I had no knowledge I could teach the man that would benefit him (ouden mathêma epistamenos, ho didaxas anthrôpon ôphelêsaim' an), but I thought that through my love I could make him better (beltiô poiêsai) by associating (sunousian) with him" (fragment 12 Nestle). But see Forster, "Profession," 12-13, for a different reading of this passage.
}

PLATO, The electronic Journal of the International Plato Society, 12, 2012.

http://gramata.univ-paris1.fr/Plato/article117.html,

(C) All rights of reproduction of any form reserved. 
This is anything but the mindless practice of virtue criticized in the Republic and Phaedo and typified in the habits Meno acquired from Gorgias. One can fully acquire the virtues only by practicing them under the guidance of another in the full and continuing awareness of the insufficiency of one's own knowledge. For the author of the Meno, virtue both is and is acquired through the sustained practice of aporia. ${ }^{57}$

\section{4.}

Though the flaws in Meno's character have terrible-if not tragicconsequences, ${ }^{58}$ they would certainly seem to be corrigible under the proper influence. Otherwise, no one once started on the wrong path could hope to reform and become virtuous. Should Socrates be faulted, then, for not doing more to save Meno from himself? ${ }^{59}$ I hope it is clear by now that such a question is misdirected. The character Socrates does nothing more or less than what Plato wants him to do, and so for that reason is blameless.

More importantly, there was nothing more that Plato needed to do. The historical Meno was past redemption, dead fifteen years or more at the hands of his hereditary guest friend the Great King when Plato chose to use him as a character in a dialogue on virtue and its acquisition. ${ }^{60}$ Plato's concern-in the

\footnotetext{
${ }^{57}$ My position is anticipated by Halper ("Lesson") who argues, as I do, that, although virtue cannot be taught, it can be learned, identifying virtue with Socratic inquiry. Gordon, Turning, 94, says that though virtue can't be taught "it can be induced by other means," specifically by dialectical engagement, but does not relate this to practice (see especially her conclusion on $\mathrm{p}$. 115). Similarly, both Gonzalez (Dialectic, 172-73) and Wilkes ("Conclusions") link virtue and inquiry but gloss over practice. And though I agree with Weiss that perplexity is meant to lead to a recognition of the limitations on all human knowledge (and not just the limited knowledge of the perplexed individual) and is therefore crucial in acquiring virtue and the human wisdom Socrates speaks of in the Apology, I think she errs by making epimeleia (which she translates as diligence) something distinct from the opening option of practice; Weiss, Cave, 170.

${ }^{58} \mathrm{His}$ fate might have seemed tragic if either Plato or Xenophon had shown Meno exhibiting some sign of inner struggle over the life he had chosen. But despite Jowett's calling him a "Thessalian Alcibiades" (cited by Klein, Commentary, 37, and already disputed by Thompson, Meno, xix), Meno as depicted by Plato lacks Alcibiades' great soul in turmoil, embracing both comic and tragic elements.

59 Throughout her book, Weiss seems intent on defending Socrates against the charge of not caring sufficiently for Meno's welfare; see, for instance, Weiss, Cave, 127-30. In a similar vein, Dimas ("Teachers," 18) argues that Socrates did not know what virtue is because it would have been immoral for Socrates not to tell Meno outright if he in fact knew it.

${ }^{60}$ The dramatic date of the Meno seems to be fixable with remarkable precision to early 402 . See Sharples, Meno, 17; Bluck, Plato's Meno, 120-24. Meno the character in the dialogue cannot be blamed any more than Plato's character Socrates in that he too says only what Plato wants him to say. That does not mean, of course, that his moral and intellectual shortcomings aren't meant as a warning to the reader.
}

PLATO, The electronic Journal of the International Plato Society, 12, 2012.

http://gramata.univ-paris1.fr/Plato/article117.html,

(c) All rights of reproduction of any form reserved. 
Meno as in all the dialogues-is for the reader. ${ }^{61}$ The question he must have asked as he plotted out the dialogue was how could he rouse the reader from moral and intellectual complacency? How could he encourage the reader to share in the inquiry with "Socrates" - the real Socrates, too, of course was $\mathrm{dead}^{62}$ - to share in the perplexity of one who knows he does not know? How, to ask the same question differently, could he prompt the reader to engage in the essential practice of reflection upon his or her own life? Only (he seems to have decided) by showing the failure of an interlocutor and the obstacle standing in the way of his - and therefore, the reader's-progress.

This is the strategy Plato employs in perhaps a dozen dialogues, even at the risk of making Socrates sometimes seem a failure. Of the earlier of those roughly dozen, the Meno stands out as an artistic culmination. It heralds a mastery of literary form in the service of philosophic argument in that the failure of the inquiry follows directly from a character's refusal to engage in the very practice that was the answer to the central philosophical question. Neither the omission of practice by Meno following the geometry lesson nor Socrates' failure to mention practice at the end of the dialogue requires us to resort to a variant reading from an inferior manuscript to be explained. ${ }^{63}$

In the dialogue's closing lines, Plato allows Socrates to treat Meno's reduced set of options as if they had been the only possibilities from the start. When virtue is shown not to be teachable, Plato makes Meno carelessly accept the 'none-of-the-above' option-virtue as a mindless gift of the gods-as if it were the only remaining possibility, even as Plato places an ever-mindful Teiresias before Meno and the reader. Plato deliberately has his characters pass over the possibility of acquiring virtue through practice-an option waiting to be recognized by anyone who returns, as Plato hints that the reader should do, to the beginning "of the whole inquiry and discussion" with the ensuing failures and omissions of the discussion in mind. By letting the increasingly futile dialogue run to its end and then pointing the reader back to the beginning, Plato both tells a tale of failure and shows the route toward virtue's acquisition. The characters

${ }^{61}$ Various commentators have made this point in different ways. See for instance Sayre, Garden, pp. 27-32, 59-64; Gordon, Turnings, Chp. 2, "Reader"; Sallis, Being and Logos, 17-22; Klein, Commentary, 3-10. Pierre Hadot draws a nice distinction between the intent of the dialogues as "forming" rather than "informing" the reader on pages 73-74 of What is Ancient Philosophy? translated by Michael Chase (Cambridge: Harvard University Press, 2002; originally published as Qu'est-ce que la philosphie antique? Paris: Éditions Gallimard, 1995).

${ }^{62}$ Could this be the point of the enigmatic quotation of Pindar Fr. 127 at 81b8-c4, that among the dead those with great wisdom return to the earth as heroes? See further Klein, Commentary, 92-95.

${ }^{63}$ F's omission of askêsis can be explained as an ancient anticipation of the modern puzzlement over Plato's not directly addressing the option in the rest of the dialogue. My guess is that an ancient editor adopted the simple if crude solution of excising the puzzling term at its first and only appearance, though Reuter's explanation of its exclusion from On Virtue as the result of a certain prejudice ("Gift", 86) is also plausible.

PLATO, The electronic Journal of the International Plato Society, 12, 2012.

http://gramata.univ-paris1.fr/Plato/article117.html,

(C) All rights of reproduction of any form reserved. 
Meno and Socrates fail in their attempt to define virtue, and Plato's Socrates makes Meno only marginally better at best. But for the attentive reader, who may submit to the discipline Meno refuses to form, Plato cannot be said to have failed at all. The art of the Meno is that Plato illustrates essential lessons about virtue and its acquisition not just despite the failure of its characters, but by means of it. $^{64}$

William WIANS

Merrimack College and Boston College

\footnotetext{
${ }^{64}$ It is a pleasure to thank Karen Newman for her perceptive reading of an earlier version of this paper and for stimulating discussions of its themes. I am grateful to Marina McCoy for searching comments on the paper's penultimate version. For other helpful comments I thank Fred Miller, Michael Brady, and John Lewis, and members of the audience at the 2009 meeting of the Ancient Philosophy Society, including Mitch Miller, Debra Nails, Jill Gordon, and especially Yancy Dominick, my commentator on that occasion. I am also grateful for comments from two anonymous referees.
}

PLATO, The electronic Journal of the International Plato Society, 12, 2012.

http://gramata.univ-paris1.fr/Plato/article117.html,

(c) All rights of reproduction of any form reserved. 